\title{
Social Appearance Anxiety, Automatic Thoughts, Psychological Well-Being and Social Media Addiction in University Students
}

\author{
Hazal Rümeysa Aslan ${ }^{1} \&$ Özlem Çakmak Tolan ${ }^{2}$ \\ ${ }^{1}$ Institute of Social Science, Department of Psychology, Dicle University, Diyarbakır, Turkey \\ ${ }^{2}$ Faculty of Letters, Department of Psychology, Dicle University, Diyarbakır, Turkey \\ Correspondence: Özlem Çakmak Tolan, Faculty of Letters, Department of Psychology, Dicle University, \\ Diyarbakır, Turkey.
}

Received: July 8, 2021

Accepted: September 17, 2021

Online Published: January 17, 2022

doi:10.5539/ies.v15n1p47

URL: https://doi.org/10.5539/ies.v15n1p47

\begin{abstract}
This study aimed to determine the relationships between social appearance anxiety, automatic thoughts, psychological well-being and social media addiction and the predictive power of these variables on social media addiction. The sample of the study consists of 440 associate degrees, undergraduate and postgraduate students studying in various universities in Turkey. Demographic Information Form, Social Media Addiction Scale, Automatic Thoughts Scale and Psychological Well-being Scale were used as data collection tools in the study. Independent group t-test, one-way ANOVA, Pearson correlation coefficient and hierarchical regression analysis methods were used for the analysis of the obtained data. As a result of the analysis, it was found that there was a positive correlation between social appearance anxiety, automatic thoughts and social media addiction and a negative correlation between social media addiction and psychological well-being. According to the analysis, it was concluded that automatic thoughts and social appearance anxiety significantly predicted social media addiction, while psychological well-being did not significantly contribute to the model. Findings were discussed in light of the relevant literature.
\end{abstract}

Keywords: automatic thoughts, social appearance anxiety, social media addiction, psychological well-being, university students

\section{Introduction}

The internet, which is a modern way of obtaining information and communicating with others, has become an increasingly important element of human life (Odac1 \& Kalkan, 2010). Nowadays, the use of the Internet, especially among young people, is increasing day by day. As the Internet becomes easily accessible and widespread around the world, its impact on people's lives is increasing. With the widespread use of the Internet, it is estimated that between 1 and 8 percent of internet users become addicted (Nakaya, 2015). Individuals easily access all kinds of information on the Internet and use the Internet for social, educational and entertainment purposes (Dogruer, Eyyam, \& Menevis, 2011). According to Turkish Statistical Institute (TSI) 2020 data, individuals use the internet mostly for purposes such as messaging, making audio or video calls over the internet, using social media, watching videos, following news and newspapers, searching for information about goods and services, searching for health-related information and listening to music. For internet usage purposes, social media usage is third with $80.2 \%$.

The first variable discussed in the current research is social media addiction. Social media is an instrument that allows people to communicate without the limitation of time and place, and to make various sharing and discussions online (Vural \& Bat, 2010). People have started to use social media networks for many kinds of social and entertainment activities such as spending time, communicating, sending pictures, playing games (Allen et al., 2014). Social media can be classified into different categories, including social networking (e.g., Facebook), professional networking (e.g., Linkedin), video sharing (e.g., YouTube), knowledge-blogging (e.g., personal blogging), and microblogging (e.g., Twitter) (Balakrishnan \& Griffiths, 2017).

Regarding the increase in people's interaction with social media, according to the latest data from Hootsuite Digital (2021), it has been determined that a typical social media user spends 2 hours and 25 minutes on social media every day. This shows that individuals spend time on social media at a time that corresponds to 
approximately one day of their life every week. Assuming that the average person sleeps 7 to 8 hours a day, this means that individuals spend about $42 \%$ of their waking lives online and spend almost as much time using the internet as they are asleep. Although there are various social media platforms in the report published by Hootsuite Digital every year, it is seen that Facebook, YouTube and WhatsApp are the three most frequently used social media platforms in the world (Kemp, 2021).

Social media addiction is a prominent issue in today's world where the use of social media is extremely widespread (Aktan, 2018a). The phenomenon of addiction comes up when the amount and duration of individuals' use of social media networks are high (Çiftçi, 2018). Social media addiction can be mentioned when individuals cannot control their use of social media and start to use social media at a level that prevents other life tasks (Ryan, Chester, Reece, \& Xenos, 2014). Social media addiction can be seen as a kind of internet addiction (Kuss \& Griffiths, 2011). In some cases, individuals may feel compelled to continue using their online social networks, which may lead to excessive use of social networking sites (Griffiths, 2013). Similar to substance addiction, social media addiction includes the experience of classic addiction symptoms (Kuss \& Griffiths, 2011). According to Griffiths (2000), these classic addiction symptoms are categorized into six domains (salience, mood modification, tolerance, withdrawal, interpersonal conflict and relapse). Any behavior that meets these six criteria, including social networks, is considered an addiction (Griffiths, 2000). Being caught up in social media, always wanting to be online on social media, being driven by uncontrollable impulses and being negatively affected in other areas of life due to this situation are considered as symptoms of social media addiction (Andreassen \& Pallesen, 2014). Although social media addiction has not yet been included in the diagnostic and statistical manual, it is thought that social media addiction, as a type of behavioral addiction, points to an important problem that affects the lives of individuals (Sagar, 2019).

When the relevant literature is examined, it is seen that social media addiction affects the lives of individuals, both psychologically and physiologically (Kızılkaplan, 2018). Although social media has a positive effect on children and young people in terms of teaching social skills, strengthening relationships and being fun, the constant and excessive use of social media platforms harms the mental health and psychological well-being of especially young users. Studies show that the use of social media can cause problems such as anxiety, stress and depression in young people (Royal Society for Public Health [RSPH], 2017). Sampasa-Kanyinga and Lewis (2015) stated that young people who reported using social media for more than 2 hours daily were more likely to report anxiety and depression symptoms and suicidal ideation. In a study conducted among young people in England aged between 14 and 24, it was found that social media platforms such as Facebook, Twitter and Instagram have a detrimental effect on many psychological problems, including sleep problems, anxiety and depression (RSPH, 2017). In the research conducted by Anxiety UK (2002), it was determined that social media feeds anxiety and increases feelings of inadequacy. There is a lot of research that the increased use of technology such as the internet, social media and smartphones, which can cause addiction in daily life, is a risk factor for depression. These studies show that these types of addiction are positively associated with depression (Glazzard \& Stones, 2019; Keles, McCrae, \& Grealish, 2019; Woods \& Scott, 2016). In the relevant literature, it has been found that social media addiction is associated with negative body image. When young individuals look at the "ideal" body images on social media platforms and compare them with their bodies, this can result in lower body esteem (Glazzard \& Stones, 2019). Unrealistic expectations revealed by social media can also cause feelings of self-consciousness, low self-esteem and perfectionism seeking, which may appear as anxiety disorders in young individuals (RSPH, 2017). In addition, studies have shown that social media usage is associated with social anxiety symptoms (Aktan, 2018b; Becker, Alzahabi, \& Hopwood, 2013; Dobrean \& Păsărelu, 2016).

Another variable examined in the current research is social appearance anxiety. Nowadays, it is thought that individuals have begun to place more importance on their physical appearance, especially with the influence of the media (Haspolat \& Kağan, 2017). The feelings, thoughts and perceptions of individuals regarding their bodies and appearance are called body image (Cash et al., 2002). Social appearance anxiety emerges as a result of the negative body image that individuals develop regarding their own body and appearance (Doğan, 2010). Appearance anxiety is directly related to body image perception, which is related to how individuals perceive their bodies (Cash \& Fleming, 2002).

Social appearance anxiety, known as a kind of social anxiety, is defined as the anxiety experienced by individuals when their physical appearance is evaluated by other individuals (Doğan, 2010). According to Hart et al. (2008); social appearance anxiety is a more comprehensive and holistic concept that includes not only general physical appearance, such as height and weight but also features such as skin color and face shape. It includes features that determine the face shape of the individual such as skin tone, nose shape, eye shape and smile, as well as physical characteristics such as the individual's height, weight, muscle structure and body shape (Hart et 
al., 2008).

It is stated that social appearance anxiety is positively related to social anxiety and negative body image (Claes et al., 2012). Studies have found a positive and significant relationship between body dysmorphic disorder, eating disorders and social appearance anxiety (Coles et al., 2006; Çelik, Turan, \& Arıc1, 2014; Hart et al., 2008). In addition, individuals with high levels of perfectionism were found to have high levels of social appearance anxiety (Kang, Johnson \& Kim, 2013). According to studies, exposure to one's own body image on social media leads to social comparison, which is closely related to appearance concerns (Fardouly, Diedrichs, Vartanian, \& Halliwell, 2015). In the study conducted by Ayar, Gerçeker, Özdemir, and Bektaş (2018), a positive and significant relationship was found between nomophobia levels, problematic internet use, social media addiction level and social appearance anxiety. In addition, it is stated that social appearance anxiety tends to decrease when the feedback about an individual's social media profile is positive and increase when the feedback is negative (Boursier, Gioia, \& Griffiths, 2020).

One of the variables discussed in the current research is automatic thoughts. The cognitive model, which states that the basis of psychological disorders is the individual's inaccurate, distorted interpretations, and deals with psychopathology within the framework of negative automatic thoughts, intermediate beliefs and core beliefs. According to the cognitive model, individuals' perceptions, interpretations and cognitions play an important role in their psychological reactions. Automatic thoughts are situation-specific cognitions that come to the mind spontaneously, occur in certain situations and take place in the mindstream (Türkçapar, 2011). These thoughts are generally brief, concise and quick (Beck, 2011). They are also known as thoughts that appear as words, pictures or memories that appear instantly in the mind of the individuals in their daily life (Greenberger \& Padesky, 2012). The person is usually unaware of these thoughts but becomes aware of the emotional reactions that the thoughts bring (Beck, 2011). Automatic thoughts are not unique to individuals with psychological problems and are found in every person. In individuals with psychological problems, these thoughts are generally distorted or exaggerated (Sharf, 2000). For this reason, it is important to determine the automatic thoughts that have a great place in the life of the individual, to evaluate whether these thoughts are functional or not, and to replace the dysfunctional thoughts with functional thoughts (Türkçapar, 2018).

The last variable addressed in the current research is psychological well-being. Positive psychology, which emerged as a trend that emphasizes positive and strengths rather than psychological problems, is based on the work of Seligman (2002). With the positive psychology movement, many concepts such as psychological well-being, subjective well-being and life satisfaction have begun to be investigated (Akdağ \& Çankaya, 2015). Bradburn (1969) defined the concept of psychological well-being, which is one of the positive psychology concepts, as the state in which positive affect predominates over negative. Ryff (1989b), on the other hand, criticizes the translation of Eudaimonia concept as "happiness" in Bradburn's (1969) study and emphasized that the concept of psychological well-being has deficiencies because it focuses on the balance of happiness, well-being and affects; ignoring the individual's potential for self-development, self-realization and growth. According to Keyes, Shmotkin, and Ryff (2002), while the concept of subjective well-being formulates well-being in terms of general life satisfaction and happiness, the concept of psychological well-being is largely based on human development and the struggle with life's existential situations.

The psychological well-being model put forward by Ryff (1989a, 1989b) consists of six components: self-acceptance, positive relationships, autonomy, environmental mastery, personal growth, and purpose in life. According to this model, psychological well-being is evaluating oneself and past positively, continuing to develop and growing as an individual, believing that one's own life has a purpose and meaning, establishing positive and quality relationships with other people, effectively managing one's own life and environment and having a sense of autonomy. Accordingly, individuals who are sufficient in these six dimensions show high levels of psychological well-being (Ryff \& Singer, 2006).

When the relevant literature is examined, it is seen that psychological well-being is associated with several variables. According to studies, psychological well-being is associated with variables such as marriage (Kim \& McKenry, 2002), social support (Lincoln, 2000; Turner, 1981), physical exercise (Hassmen, Koivula, \& Uutela, 2000), internet use (Chen \& Persson, 2002) and internet addiction (Çardak, 2013). Although psychological well-being has been studied with issues such as internet use and internet addiction, few studies are examining the relationship between social media addiction and psychological well-being. In a systematic review study examining the relationship between social media and well-being by Duradoni, Innocenti, and Guazzini (2020), it was stated that most studies examined within the scope of the review found a low-level but significant relationship between social media addiction and well-being. According to a study conducted to examine the relationship between psychological well-being and the level of social media addiction with high school students 
in Turkey, there was a negative significant relationship between psychological well-being and conflict which is a sub-dimension of social media addiction, while there was no significant relationship between mood modification, occupation and relapse from the sub-dimensions of social media addiction and psychological well-being (Söner \& Y1lmaz, 2018).

The main purpose of this study is to examine the relationships between social appearance anxiety, automatic thoughts and psychological well-being, which are thought to affect university students' social media addiction. There is a gap in the literature on examining the relationship between social appearance anxiety, automatic thoughts and psychological well-being and social media addiction from a holistic perspective. It is thought that this study will fill this gap in the literature. For this reason, the research questions developed in relation to the general purpose of this study are listed below.

1) Is there a significant relationship between social appearance anxiety, automatic thoughts and psychological well-being and social media addiction?

2) Is there a significant difference in terms of social media addiction among demographic variables such as gender, age, relationship status in university students?

3) Does social appearance anxiety significantly predict social media addiction?

4) Do automatic thoughts significantly predict social media addiction?

5) Does psychological well-being significantly predict social media addiction?

\section{Method}

\subsection{Research Design}

This study is descriptive research designed with the relational screening model. The relational screening model is a research design that aims to determine the existence and/or degree of covariance between two or more variables (Karasar, 2005).

\subsection{Participants Characteristic and Data Collection}

The sample of this study consists of 440 university students aged between 18 and 44 . The scales were applied to associate, undergraduate and postgraduate students who studying at different universities in Turkey. 279 (63\%) female and $161(36 \%)$ male students participated in the study. The mean age of the participants was 23.94 .

\subsection{Data Collection}

In the study, 443 individuals were reached; incomplete or incorrectly filled forms were excluded from the study and 440 questionnaire forms were evaluated. An online questionnaire form (Google Form) was prepared for data collection. It took the participants 10-20 minutes to fill in the scales. The data collection process was completed between April 2021 and May 2021.

\subsection{Measuring Tools}

\subsubsection{Personal Information Form}

It was prepared by the researchers to get information about demographic variables such as gender, age, frequency and duration of social media usage.

\subsubsection{Social Media Addiction Scale}

The Social Media Addiction Scale is a measurement tool developed by Tutgun-Ünal and Deniz (2015) to measure the social media addiction of university students. The scale consists of 41 items and 4 sub-dimensions (occupation, mood modification, relapse, conflict). A higher score obtained from the scale indicates high levels of social media addiction. The Cronbach's Alpha value, which is the internal consistency coefficient of the scale, was found to be .96 . In the current study, the Cronbach Alpha internal consistency coefficient of the scale was found to be .97 .

\subsubsection{Social Appearance Anxiety Scale}

The Social Appearance Anxiety Scale was developed by Hart et al. (2008) to measure the social appearance anxiety of individuals. The scale consists of cognitive, emotional and behavioral expressions related to the appearance concerns of individuals. It is a one-dimensional, 5-point Likert-type scale with 16 items. The Turkish adaptation of the scale was made by Doğan (2010). The Cronbach Alpha internal consistency coefficient of the scale was found to be .93 . In the current study, the Cronbach Alpha value of the scale was found to be .95 . 


\subsubsection{Automatic Thoughts Scale}

The Automatic Thoughts Scale is a self-report scale developed by Hollon and Kendall (1980) to measure the frequency of negative evaluations of individuals. It is a 5-point Likert-type scale consisting of 30 items. As a result of the factor analysis, it was stated that the scale consisted of 5 sub-dimensions: "Negative Thoughts About Self", "Negative Thoughts About Confusion and Escape", "Negative Thoughts About Personal Maladjustment", "Negative Thoughts About Loneliness", "Negative Thoughts About Hopelessness". High scores from the scale indicate that the individual's negative automatic thoughts occur frequently. Turkish validity and reliability were done by Şahin and Şahin (1992). The Cronbach Alpha internal consistency coefficient of the Turkish form was found to be .93 . In the current study, the Cronbach Alpha internal consistency coefficient of the scale was found to be 97 .

\subsubsection{Psychological Well-Being Scale}

The Psychological Well-Being Scale was developed by Diener et al. (2009) to measure psychological well-being, which includes important elements of human function, from positive relationships to feelings of efficacy, to having a meaningful and purposeful life. A high score from the scale indicates that the individual has many psychological resources and strengths. The Turkish adaptation of the scale was done by Telef (2013). In the reliability studies of the scale, the Cronbach Alpha internal consistency coefficient was found to be .80. In this study, the Cronbach Alpha internal consistency coefficient of the scale was found to be .87 .

\subsection{Analysis of Data}

SPSS 26 package program was used to analyze the data of this study. The Kurtosis-Skewness values of the variables used to determine whether the scale scores showed a normal distribution were examined and given in Table 1. The Kurtosis-Skewness values of the variables are in the range of $-1.5<\mathrm{x}<+1.5$, indicates that there is a normal distribution (Tabachnick \& Fidell, 2013). In this context, parametric tests were used in the analysis of the data. Independent sample t-test, one-way ANOVA analysis of variance, Pearson correlation and hierarchical regression analyzes was performed for hypothesis testing. While correlation analysis was used to determine the relationships between the variables for the first purpose of the study, hierarchical regression analysis was used to determine the predictive power of each of the independent variables on social media addiction.

Table 1. Skewness and kurtosis values of variables

\begin{tabular}{ccc}
\hline & Skewness & Kurtosis \\
\hline Social Media Addiction Scale & .793 & .343 \\
Social Appearance Anxiety Scale & 1.030 & .262 \\
Automatic Thoughts Scale & .715 & -.358 \\
Psychological Well-Being Scale & -.694 & .502 \\
\hline
\end{tabular}

\section{Results}

Based on data analysis, the findings of the study are presented below.

The study has been fulfilled with 440 students over different universities in Turkey. Demographic information about the participants is shown in Table 2. 
Table 2. Demographic information of participants

\begin{tabular}{|c|c|c|c|c|c|c|c|}
\hline Variable & & $\mathrm{N}$ & $\%$ & Variable & & $\mathrm{N}$ & $\%$ \\
\hline \multirow{4}{*}{ Gender } & \multirow{2}{*}{ Female } & \multirow{2}{*}{279} & \multirow{2}{*}{63.4} & \multirow{4}{*}{ Duration of Social Media Usage } & Less than 1 year & 16 & 3.6 \\
\hline & & & & & $1-2$ years & 39 & 8.9 \\
\hline & \multirow{2}{*}{ Male } & \multirow{2}{*}{161} & \multirow{2}{*}{36.6} & & 3-4 years & 77 & 17.5 \\
\hline & & & & & More than 5 years & 308 & 70.0 \\
\hline \multirow{5}{*}{ Age } & \multirow{5}{*}{$18-44$} & \multirow{5}{*}{440} & \multirow{5}{*}{100} & \multirow{5}{*}{ Daily Time Spent on the Social Media } & $0-2$ hours & 102 & 23.1 \\
\hline & & & & & 2-4 hours & 172 & 39.1 \\
\hline & & & & & 4-6 hours & 107 & 24.3 \\
\hline & & & & & 6-8 hours & 42 & 9.5 \\
\hline & & & & & $\begin{array}{c}\text { More than } 8 \\
\text { hours }\end{array}$ & 17 & 3.9 \\
\hline \multirow{4}{*}{ Level of Education } & Associate & 66 & 15 & \multirow{4}{*}{$\begin{array}{c}\text { Daily Frequency of Visiting Social } \\
\text { Media Platforms }\end{array}$} & 1 time or less & 14 & 3.2 \\
\hline & Undergraduate & 237 & 53.9 & & $2-4$ times & 118 & 26.8 \\
\hline & \multirow[b]{2}{*}{ Postgraduate } & \multirow[b]{2}{*}{137} & \multirow[b]{2}{*}{31.1} & & 5 times and more & 303 & 68.9 \\
\hline & & & & & $\begin{array}{c}\text { Several times a } \\
\text { week } \\
\end{array}$ & 5 & 1.1 \\
\hline \multirow{4}{*}{ Relationship Status } & \multirow{2}{*}{ Single } & \multirow{2}{*}{271} & \multirow{2}{*}{61.6} & \multirow{4}{*}{ Daily Number of Social Media Shares } & $0-10$ & 414 & 94.1 \\
\hline & & & & & $11-20$ & 13 & 3.0 \\
\hline & \multirow{2}{*}{ In relationship } & \multirow{2}{*}{169} & \multirow{2}{*}{38.4} & & $21-30$ & 8 & 1.8 \\
\hline & & & & & 41 and more & 5 & 1.1 \\
\hline \multirow{4}{*}{$\begin{array}{c}\text { Perceived Socioeconomic } \\
\text { Status }\end{array}$} & Low & 82 & 18.6 & \multirow{4}{*}{ Number of Social Media Followers } & Less than 100 & 91 & 20.7 \\
\hline & Medium & 315 & 71.6 & & $100-500$ & 233 & 53.0 \\
\hline & \multirow{2}{*}{ High } & \multirow{2}{*}{43} & \multirow{2}{*}{9.8} & & $501-1000$ & 73 & 16.6 \\
\hline & & & & & 1001 and more & 43 & 9.8 \\
\hline
\end{tabular}

The independent samples t-test to determine whether there is a significant difference between the social media addiction levels of the participants according to the gender variable is presented in Table 3 . According to the results of the independent samples t-test analysis, no significant difference was found between the social media addiction levels of students compared to the male and female students $(\mathrm{p}>0.05)$.

Table 3. T-test comparison of students' social media addiction levels according to their gender

\begin{tabular}{|c|c|c|c|c|c|c|c|}
\hline \multirow{2}{*}{ Variable } & \multirow{2}{*}{ Groups } & \multirow{2}{*}{$N$} & \multirow{2}{*}{$X$} & \multirow{2}{*}{$S s$} & \multicolumn{3}{|c|}{ t-test } \\
\hline & & & & & $t$ & $s d$ & $p$ \\
\hline \multirow{2}{*}{ Gender } & Woman & 279 & 2.20 & .84 & \multirow{2}{*}{-.543} & \multirow{2}{*}{438} & \multirow{2}{*}{.588} \\
\hline & Man & 161 & 2.24 & .79 & & & \\
\hline
\end{tabular}

A one-way ANOVA analysis was conducted to determine whether the social media addiction levels of the participants differ according to variables such as age, socio-economic level, education level, daily time spent on the social media, daily frequency of visiting social media platforms, the daily number of social media shares and the number of social media followers is presented in Table 4. As a result of the ANOVA analysis, it was found that social media addiction did not differ in terms of age, socio-economic level and education level ( $p>.05)$. A significant difference was found between the time and frequency of daily use of social media, the number of daily social media shares and the number of followers and social media addiction $(\mathrm{p}<.05)$. It was observed that the average social media addiction scores increased as the daily time spent on social media and daily frequency of visiting social media platforms increased. 
Table 4. One-way ANOVA results for variables of social media usage

\begin{tabular}{|c|c|c|c|c|c|c|}
\hline & & Sum of Square & $\mathrm{df}$ & Mean Square & $\mathrm{F}$ & Sig. \\
\hline \multirow{3}{*}{ Daily Time Spent on the Social Media } & Between Groups & 56.764 & 4 & 14.191 & & \\
\hline & Within Groups & 230.738 & 435 & .530 & 26.754 & .000 \\
\hline & Total & 287.502 & 439 & & & \\
\hline \multirow{3}{*}{ Daily Frequency of Visiting Social Media Platforms } & Between Groups & 24,369 & 3 & 8,123 & & \\
\hline & Within Groups & 263,133 & 436 & ,604 & 13,460 & .000 \\
\hline & Total & 287,502 & 439 & & & \\
\hline \multirow{3}{*}{ Daily Number of Social Media Shares } & Between Groups & 10.458 & 3 & 3.486 & & \\
\hline & Within Groups & 277.045 & 436 & .635 & 5.486 & .001 \\
\hline & Total & 287.502 & 439 & & & \\
\hline \multirow{3}{*}{ Number of Social Media Followers } & Between Groups & 5.269 & 3 & 1.756 & & \\
\hline & Within Groups & 282.233 & 436 &, 647 & 2.713 & .044 \\
\hline & Total & 287.502 & 439 & & & \\
\hline
\end{tabular}

The results of the correlation analysis performed to determine the relationship between social media addiction and social appearance anxiety, automatic thoughts and psychological well-being variables are presented in Table 5 .

Table 5. Correlation coefficients between university students' social media addiction and social appearance anxiety, automatic thoughts and psychological well-being

\begin{tabular}{lcccc}
\hline & 1 & 2 & 3 & 4 \\
\hline 1. Social Media Addiction & - & $.324^{* *}$ & $.468^{* *}$ & $-.316^{* *}$ \\
2. Social Appearance Anxiety & - & $.382^{* *}$ & $-.293^{* *}$ \\
3. Automatic Thoughts & & & - & $-.647^{* *}$ \\
4. Psychological Well-Being & & & - \\
\hline
\end{tabular}

Note. ${ }^{*} \mathrm{p}<.05 ; * \mathrm{p}<.01$.

When Table 5 is examined, it is seen that there is a significant relationship between university students' social media addictions and social appearance anxiety, automatic thoughts and psychological well-being. It is seen that there are positive relationships between social media addiction and social appearance anxiety $(\mathrm{r}=.324, \mathrm{p}<.01)$ and automatic thoughts $(\mathrm{r}=.468, \mathrm{p}<.01)$ and a negative relationship between psychological well-being $(\mathrm{r}=.316$, $\mathrm{p}<.01)$

Hierarchical regression analysis was performed to determine the predictive power of social appearance anxiety, automatic thoughts and psychological well-being variables on social media addiction. The findings are presented in Table 6.

Table 6. Hierarchical regression analysis results related to the prediction of social media addiction.

Note. ${ }^{*} \mathrm{p}<.05, * * \mathrm{p}<.01$

\begin{tabular}{ccccccc}
\hline Model & Variable & $\mathrm{R}$ & $\mathrm{R}^{2}$ & $\Delta \mathrm{R}^{2}$ & $\beta$ & $\mathrm{t}$ \\
\hline \multirow{2}{*}{ Step 1 } & Constant & .468 & .219 & .217 & & $16.340^{* *}$ \\
& Automatic Thoughts & & & & .468 & $11.078^{* *}$ \\
\hline \multirow{4}{*}{ Step 2 } & Constants & .494 & .244 & .240 & & $12.598^{* *}$ \\
& Automatic Thoughts & & & & .403 & $8.950^{* *}$ \\
& Social Appearance Anxiety & & & & .170 & $3.785^{* *}$ \\
\hline \multirow{4}{*}{ Step 3 } & Constants & .494 & .244 & .238 & & $4.242^{* *}$ \\
& Automatic Thoughts & & & & .397 & $7.006^{* *}$ \\
& Social Appearance Anxiety & & & & .170 & $3.760^{* *}$ \\
& Psychological Well-Being & & & & -.010 & -.180 \\
\hline
\end{tabular}

When Table 6 is examined, it is observed that the variable of automatic thoughts that was analyzed in the first 
step of hierarchical regression analysis predicts social media addiction most and its contribution to the model was found to be significant $(\mathrm{p}<.05)$. When the $\mathrm{R}^{2}$ values in Table 5 are examined, it is seen that automatic thoughts, one of the variables that predict social media addiction, explain $21 \%$ of the total variance. In the second step, with the inclusion of social appearance anxiety in the model, the total variance increased to $24 \%$. The psychological well-being variable was added to the model in the third step. It is seen that the variable of psychological well-being did not significantly predict social media addiction $(p>05)$. According to the hierarchical regression analysis results, automatic thoughts, social appearance anxiety and psychological well-being variables explain $24.4 \%$ of the total variance regarding the social media addiction levels of university students $\left(\mathrm{R}^{2}=0.244, \mathrm{p}<.05\right)$. As a result of hierarchical regression analysis, it was found that the most important contribution in predicting social media addiction came from the variable of automatic thoughts $(\beta=.468)$, followed by social appearance anxiety $(\beta=.170)$ and psychological well-being variables $(\beta=-.010)$. When the aspects of the relationships between the variables were examined, it was seen that university students' automatic thoughts and social appearance concerns predicted their social media addiction levels positively. On the other hand, it was found that the variable of psychological well-being negatively predicted the level of social media addiction.

\section{Discussion}

In the current study, the relationships between social media addictions and social appearance anxiety, automatic thoughts and psychological well-being levels of university students were examined. In the study, it was seen that social media addiction and social appearance anxiety, automatic thoughts and psychological well-being variables were all correlated with each other. In addition, automatic thoughts and social appearance anxiety had predictive power on social media addiction, while psychological well-being did not have predictive power on social media addiction.

Primarily, in the current study, the relationships between social media addiction and certain socio-demographic variables were examined. First, social media addiction scores were evaluated in terms of gender and it was found that social media addiction did not show a significant difference according to gender. Consistent with the findings in the relevant literature, studies are showing that social media addiction does not show a statistically significant difference according to gender (Abbasi, 2019; Aktan, 2018a; Baz, 2018; Kırı, Aslan, Çetinkaya, \& Gül, 2015; Müller et al., 2016; Radmard, Kutluca, \& Türk, 2020). However, according to some studies, it has been found that social media addiction differs according to gender, and women's social media addiction levels are higher than men (Daşlı \& Baloğlu, 2020; İnce \& Koçak, 2017; Martinez-Ferrer, Moreno, \& Musitu, 2018; Şahin \& Öztoprak, 2019). In the study conducted by Tutgun-Ünal and Deniz (2016), in which social media addictions of university students were examined, it was revealed that social media addiction did not show a difference according to gender, but when the sub-scales of social media addiction were examined, the sub-dimensions of occupation and mood modification were in favor of women; the conflict sub-dimension differs in favor of men. In the relapse sub-dimension, it was found that there was no difference according to gender. As the reason for this difference; it can be said that women are more mentally attached to social media than men, they receive more emotional support from social media while men are more in conflict with social media than women and are more negatively affected by social media (Tutgun-Ünal \& Deniz, 2016). In the current study, although female participants spend more hours on social media per day, no difference was found between male and female participants in social media addiction.

When the participants' characteristics of social media usage were examined, it was found that the social media addiction scores of the participants differed in terms of daily social media usage time and frequency and the number of social media followers and shares. It was observed that as the duration of social media use of the participants increased, their social media addictions also increased. When the relevant literature is examined, it is seen that the studies are consistent with the findings obtained from the current study (Aktan, 2018a; Radmard et al., 2020; Tutgun-Ünal \& Deniz, 2016). It was observed that as the frequency of daily use of social media increased, the social media addiction scores of the participants also increased. In the current study, the average scores of the group that used social media more than 5 times a day showed that individuals were highly/very highly dependent on social media. In the study of Kırık et al. (2015), it was determined that there was a significant difference between the frequency of daily visits to social media platforms and the levels of social media addiction. In the light of this information, it is thought that the social media addiction of individuals' increases as the time spent on social media and the frequency of visiting social media increase.

People use social networks for various reasons. Social media, nowadays, is used for various reasons such as sharing photos, entertainment, making use of free time, accessing information, communicating, and being up to date (Solmaz, Tekin, Herzem \& Demir, 2013). Although the reasons for the use of individuals differ, today the 
use of social media comes to the fore due to communicating with family and friends, accessing information and having fun (Eren, 2014). In the current study, when the findings of the participants' reasons for using social media are examined, among the reasons for the use of social media by the participants; obtaining information, reading/sharing news, communicating and being informed about friends are in the first place. In this study, the majority of the students (82.95\%) who participated in the study stated that they used social media to obtain information. In the study conducted by Solmaz et al. (2013), it was stated that university students who participated in the study mostly used social media to access information. In the study of Çömlekçi and Başol (2019) in which they examined the relationship between social media purposes and social media addiction of young people, it was found that participants mostly used social networks for entertainment, communication and following the agenda.

When the most frequently used social media platforms of the student's participants are examined; social media platforms such as WhatsApp (97.04\%), Instagram (86.81\%), YouTube (80.9\%), Twitter (61.36\%) and Facebook (42.5\%) came to the fore, respectively. Consistent with the current research findings, according to We Are Social's internet and social media usage statistics for 2021, the mobile application with the most users in Turkey was found to be WhatsApp. However, when the most frequently used social media platform is examined, it is seen that the most used social media platform is Facebook (98.9\%) in the world and YouTube (94.5\%) in Turkey. When the relevant literature is examined, the findings about the most frequently used social media platforms in Turkey are complicated. The studies show that the most frequently used platforms are Whatsapp (Sagar, 2019; Tosuntaş, 2020), Instagram (Bilge, Baydili, \& Göktaş, 2020; Caz \& Bardakçı, 2019) and Facebook (Gazi, Çetin, \& Çak1, 2017; Vural \& Bat, 2010).

For the purpose of the current study, the relationships between social media addiction and social appearance anxiety, automatic thoughts and psychological well-being of university students were examined. According to the results of the correlation analysis performed to determine the relationship between the variables, there was a positive relationship between social media addiction and social appearance anxiety and automatic thoughts and a negative relationship with psychological well-being. In the relevant literature, no study has been found that examines the relationship between social appearance anxiety, automatic thoughts, psychological well-being and social media addiction. However, in Değirmenci's (2020) study to determine the relationship between social appearance anxiety and psychological well-being in women using social media, it was found that there is a positive significant relationship between the time spent on social media and social appearance anxiety and psychological well-being.

In the current study, the predictive powers of social appearance anxiety, automatic thoughts and psychological well-being on social media addiction were examined. As a result of hierarchical regression analyzes conducted to determine the variables that predicted the participants' social media addiction scores, it was seen that social appearance anxiety and automatic thoughts significantly predicted social media addiction scores. According to the research findings, the variable that predicts the social media addiction level the most is automatic thoughts. Accordingly, it can be said that individuals with a high level of automatic thoughts have a higher level of social media addiction. These findings support Young's (1999) view that negative core beliefs can be associated with pathological internet use to overcome perceived inadequacies. Dysfunctional automatic thoughts, intermediate beliefs and core beliefs have an undeniable contribution to the development of internet addiction (Erden \& Hatun, 2015). Perhaps the most central factor in the cognitive-behavioral model of problematic internet use is the presence of maladaptive cognitions. Dissonant cognitions can be divided into thoughts about the self and thoughts about the world. Negative thoughts about oneself cause people to use the internet to get more positive responses from others. Cognitive distortions about the world involve generalizing specific events to universal conclusions. In other words, the individual may think "The Internet is the only place I am respected" or "The Internet is my only friend". This all-or-nothing thinking is considered a maladaptive cognitive distortion that exacerbates an individual's internet addiction. These cognitive distortions occur automatically when an internet-related stimulus is present. Problematic internet use may occur as a result of such maladaptive cognitions (Davis, 2001).

Although studies show that core negative beliefs and cognitive distortions contribute to pathological internet use and internet addiction, few studies are examining the relationship between social media addiction and automatic thoughts. In the study of Yığman, Aksu, Özdel, and Ünver (2021), it was stated that dysfunctional attitudes are associated with social media addiction both directly and through automatic thoughts (Ylğman et al., 2021). According to Davis (2001), one of the factors contributing to pathological internet use is related to the individual's social context. The fact that people with socialization problems and maladaptive cognitions prefer online social interactions more was determined as the basic elements of social network addiction and these two 
factors were added to the cognitive-behavioral model of pathological internet use. In the light of this information, it is necessary to consider that the internet and social media addiction should not only be seen as a behavioral problem but also that cognitive processes play a major role in the background of behavior (Dinç, 2020). In this framework, it is thought that the dysfunctional thoughts of individuals on the development of social relations and their possible psychological needs to be met in social media are influential on the development of social media addiction.

As a result of the analyzes made in the context of predicting social media addiction according to social appearance anxiety, it is seen that social appearance anxiety has a positive predictive power of social media addiction. Consistent with the findings of the present study, the study by Dogan and Çolak (2016) concluded that social appearance anxiety is an important predictor of social network use. In a study by Stice and Shaw (1994), it was stated that exposure to the thin-ideal body image portrayed on social media leads to depression, stress, unhappiness, guilt, shame and insecurity. It has also been found that exposure to these ideal body images leads to increased body dissatisfaction. It is thought that this situation affects the emergence of social appearance anxiety.

Overexposure to visual content on social media can lead individuals to make more social comparisons. Therefore, digital activities based on body image can potentially lead to problematic social media use by allowing individuals who are dissatisfied with their appearance to create and manage their best online self-presentations (Boursier et al., 2020). In Kocaman's (2020) study, it was concluded that as the addiction of adolescents on the Instagram application, which directly affects their body image, increases, their social appearance anxiety increases as well. In the study of Boursier et al. (2020), a strong relationship was found between selfie expectations, social appearance anxiety and problematic social media use, especially among boys. In the study, it was found that the boys' anxiety about their appearance and the expectation that selfies could increase their self-confidence were predictors of problematic social media use, but although the girls had a higher level of social appearance anxiety, their social media use was not affected. Dogan and Çolak (2016) stated that men who are concerned about their appearance can use social media as a protective shield that meets their needs to be in contact with others.

In a study by Eckler, Kalyango, and Paasch (2017), it was found that people who spend more time on Facebook make more comparisons about their bodies pay more attention to their own and other people's physical appearance, and women have more negative feelings about their bodies. In a study by Altındiş et al. (2017), the fact that almost half of the participants liked themselves and their photos after editing was evaluated as a reflection of people's social appearance anxiety. In addition, it is thought that it is easier for people who remain in the background in real life to find a place in the social media platforms more easily, to find friends, in other words, to socialize and therefore, the tendency of young people to use social media helps them to socialize. From this point of view, it is thought that how individuals look on social media is becoming more important, and judging a person by their appearance may cause an increase in social appearance anxiety.

Although there is a significant negative relationship between social media addiction and psychological well-being in the current study, it was observed that psychological well-being did not significantly predict the level of social media addiction. No research has been found in the relevant literature examining the effect of psychological well-being on social media addiction. When the studies conducted to examine the relationship between social media addiction and psychological well-being are examined, it is seen that the use of social media is associated with psychological well-being, but the findings are complicated. In the study of Shaw and Gant (2004), being in online communication with others was associated with a decrease in depression and loneliness levels and an increase in self-esteem and perceived social support. The use of the Internet, and especially social networks, has been associated with psychological well-being, as it allows the person to communicate and socialize (Kim \& Lee, 2011). In Tweng's (2019) study, it was stated that people who never use digital media have a lower level of psychological well-being than people who use it less. However, frequent use of social media has been associated with higher levels of stress and depression and lower levels of happiness among young individuals (Brooks, 2015).

Frequent use of social media has generally been associated with lower psychological well-being (Sabik, Falat, \& Magasnos, 2020). In the study of Sabik et al. (2020), women whose self-esteem was dependent on social media feedback reported lower levels of resilience and self-kindness, and higher levels of stress and depressive symptoms. Findings show that these women are at high risk for low psychological well-being. Burke, Marlow, and Lento (2010) stated that the use of social media may negatively affect psychological well-being by replacing the time individuals spend with their friends and families and engage in real social activities. In Twenge's (2019) study, it was concluded that the frequent use of digital media reduces psychological well-being by negatively affecting sleep duration and quality and reducing face-to-face social interaction. In the light of this information, 
it was thought that the frequent use of social media and the addiction to social media negatively affected individuals' physical health (e.g., sleep quality, physical discomfort) and social interactions (e.g., interpersonal relationships) and decreased their psychological well-being levels.

According to the study conducted by Söner and Y1lmaz (2018) with high school students, a negative significant relationship was found between psychological well-being and conflict which is one of the sub-dimensions of social media addiction, and it was seen that mental well-being significantly predicted the conflict sub-dimension of social media addiction. However, it was observed that occupation, mood regulation and relapse, which are sub-dimensions of social addiction, did not predict mental well-being. In the study of Ümmet, Alkan, Batal, and Kaya (2019), it was found that well-being is not a strong predictor of social media addictions of individuals.

The current study shows some limitations. The first limitation of the study is that the sample group consisted of only university students. Since the results obtained from the study can only be generalized to this group, it is thought that it would be beneficial to conduct similar studies with individuals of another age and education level. The second limitation of this study is that the sample was not large enough. This limitation has been a factor that limits the generalizability of the study findings. As the third limitation, it can be shown that the research includes a cross-sectional research process. To overcome this limitation, it is recommended to contribute to the literature by adding longitudinal studies and different variables.

When the research results are evaluated in general, it is seen that social media has a very important place in the lives of young people. Although there are studies on internet and social media use in the literature, studies on social media addiction are relatively few. Specifically, studies are needed to examine the relationship between the use and addiction of each of the most widely used social media platforms and automatic thoughts, social appearance anxiety and psychological well-being. Since Instagram is a platform based on visuality, it is thought that studies that specifically examine the relationship between social appearance anxiety and Instagram use and addiction will make an important contribution to the literature. Additionally, since the relationship between social media addiction and social appearance anxiety is complex, it is recommended to investigate whether social appearance anxiety is the cause or effect of social media addiction for future research.

\section{References}

Abbasi, I. S. (2019). Social media addiction in romantic relationships: Does user's age influence vulnerability to social media infidelity? Personality and Individual Differences, 139, 277-280. https://doi.org/10.1016/j.paid.2018.10.038

Akdağ, F. G., \& Çankaya, Z. C. (2015). Evli bireylerde psikolojik iyi oluşun yordanması. Mersin Üniversitesi Eğitim Fakültesi Dergisi, 11(3). https://doi.org/10.17860/efd.67613

Aktan, E. (2018a). Üniversite öğrencilerinin sosyal medya bağımlılık düzeylerinin çeşitli değişkenlere göre incelenmesi. Erciyes İletişim Dergisi, 5(4), 405-421. https://doi.org/10.17680/erciyesiletisim.379886

Aktan, E. (2018b). Sosyal medya ve sosyal kaygı: Sosyal medya kullanıcıları üzerine bir araştırma. Selçuk İletişim, 11(2), 35-53. https://doi.org/10.18094/josc.397272

Allen, K. A., Ryan, T., Gray, D. L., Mcinerney, D. M., \& Waters, L. (2014). Social media use and social connectedness in adolescents: the positives and the potential pitfalls. The Educational And Developmental Psychologist, 31(1), 18-31. https://doi.org/ 10.1017/edp.2014.2

Altındiş, A., Altındiş, S., Aslan, U. D. F. G., Aşıcı, N., İnci, M. B., Ekerbiçer, H. Ç., \& Tokaç, M. (2017). Sosyal Medya Ağları ve Sosyal Görünüm Anksiyetesi. International Journal of Social Science, 64, 227-235. https://doi.org/10.9761/JASSS7353

Andreassen, S. C., \& Pallesen, S. (2014). Social network site addiction-an overview. Current pharmaceutical design, 20(25), 4053-4061. https://doi.org/10.2174/13816128113199990616

Anxiety UK. (2012). Anxiety UK study finds technology can increase anxiety. Retrieved from https://www.anxietyuk.org.uk/for-some-with-anxiety-technology-can-increase-anxiety/

Ayar, D., Gerçeker, G. Ö., Özdemir, E. Z., \& Bektas, M. (2018). The effect of problematic internet use, social appearance anxiety, and social media use on nursing students' nomophobia levels. CIN: Computers, Informatics, Nursing, 36(12), 589-595. https://doi.org/10.1097/CIN.0000000000000458

Balakrishnan, J., \& Griffiths, M. D. (2017). Social media addiction: What is the role of content in YouTube? Journal of Behavioral Addictions, 6(3), 364-377. https://doi.org/10.1556/2006.6.2017.058

Baz, F. Ç. (2018). Sosyal medya bağımlılığı: Üniversite öğrencileri üzerine çalışma. OPUS Uluslararası Toplum 
Araştırmaları Dergisi, 9(16), 276-295. https://doi.org/10.26466/opus.470118

Beck J. S. (2011). Cognitive behavior therapy: Basics and beyond. Guilford Press, New York.

Becker, M. W., Alzahabi, R., \& Hopwood, C. J. (2013). Media Multitasking Is Associated with Symptoms of Depression and Social Anxiety. Cyberpsychology, Behavior, and Social Networking, 16(2), 132-135. https://doi.org/10.1089/cyber.2012.0291

Bilge, Y., Baydili, K. N., \& Göktaş, S. Ş. (2020). Sosyal Medya Bağımlılı̆̆ını Yordamada Anksiyete, Stres ve Günlük Sosyal Medya Kullanımı: Meslek Yüksekokulu Örneği. Bă̆ımlılık Dergisi, 21(3), 223-235.

Boursier, V., Gioia, F., \& Griffiths, M. D. (2020). Do selfie-expectancies and social appearance anxiety predict adolescents' problematic social media use? Computers in Human Behavior, 110, 106395. https://doi.org/10.1016/j.chb.2020.106395

Bradburn, N. M. (1969). The structure of psychological well-being. Chicago: Aldine. https://doi.org/10.1037/t10756-000

Brooks, S. (2015). Does personal social media usage affect efficiency and well-being? Computers in Human Behavior, 46, 26-37. https://doi.org/10.1016/j.chb.2014.12.053

Burke, M., Marlow, C., \& Lento, T. (2010). Social network activity and social well-being. In Proceedings of the SIGCHI conference on human factors in computing systems, 1909-1912. https://doi.org/10.1145/1753326.1753613

Cash, T. F., \& Fleming, E. C. (2002). The impact of body image experiences: development of the body image quality of life inventory. Journal of Eating Disorder, 31, 455-460. https://doi.org/10.1002/eat.10033

Cash, T. F., Fleming, E. C., Alindogan, J., Steadman, L., \& Whitehead, A. (2002). Beyond body image as a trait: The development and validation of the Body Image States Scale. Eating Disorders, 10(2), 103-113. http://doi.org/10.1080/10640260290081678

Caz, Ç., \& Bardakçı, S. (2019). Sosyal medya bozukluğu: üniversite öğrencileri üzerine bir araştırma. OPUS Uluslararası Toplum Araştırmaları Dergisi, 10(17), 1100-1124. https://doi.org/10.26466/opus.521522

Chen, Y., \& Persson, A. (2002). Internet use among young and older adults: Relation to psychological well-being. Educational Gerontology, 28(9), 731-744. https://doi.org/10.1080/03601270290099921

Claes, L., Hart, T. A., Smits, D., Van den Eynde, F., Mueller, A., \& Mitchell, J. E. (2012). Validation of the social appearance anxiety scale in female eating disorder patients. European Eating Disorders Review, 20(5), 406-409. https://doi.org/10.1002/erv.1147

Coles, M. E., Phillips, K. A., Menard, W., Pagano, M. E., Fay, C. \& Weisberg, R. B. (2006). Body dysmorphic disorder and social phobia: Cross-sectional and prospective data. Depression and Anxiety, 23, 26-33. https://doi.org/10.1002/da.20132

Çardak, M. (2013). Psychological well-being and Internet addiction among university students. Turkish Online Journal of Educational Technology-TOJET, 12(3), 134-141.

Çelik, E., Turan, M. E., \& Arıcı, N. (2014). The role of social appearance anxiety in meta-cognitive awareness of adolescents. International Journal of Learning, Teaching and Educational Research, 7(1).

Çiftçi, H. (2018). Üniversite öğrencilerinde sosyal medya bağımlılığı. MANAS Sosyal Araştırmalar Dergisi, 7(4).

Çömlekçi, M. F., \& Başol, O. (2019). Gençlerin sosyal medya kullanım amaçları ile sosyal medya bağımlılı̆̆ı ilişkisinin incelenmesi. Manisa Celal Bayar Üniversitesi Sosyal Bilimler Dergisi, 17(4), 173-188. https://doi.org/10.18026/cbayarsos.525652

Daşlı, Y., \& Baloğlu, A. O. (2020). Sosyal Medya Bağımlılı̆̆ı Üzerine Bir Alan Araştırması. International Social Mentality and Researcher Thinkers Journal, 6(33),1229-1239. https://doi.org/10.31576/smryj.572

Davis, R. A. (2001). A cognitive-behavioral model of pathological Internet use. Computers in human behavior, 17(2), 187-195. https://doi.org/10.1016/S0747-5632(00)00041-8

Değirmenci, G. (2020). Sosyal Medya Kullanan Kadınlarda Sosyal Görünüş Kaygısı ile Psikolojik Iyi Oluş İlişkisinin İncelenmesi (Unpublished master's thesis). İstanbul Okan University, Institute of Medical Sciences, İstanbul.

Diener, E., Wirtz, D., Biswas-Diener, R., Tov, W., Kim-Prieto, C., Choi, D. W., \& Oishi, S. (2009). New measures of well-being. In Assessing well-being (pp. 247-266). Springer, Dordrecht. 
https://doi.org/10.1007/978-90-481-2354-4_12

Dinç, S. B. (2020). Narsistik Kişilik Örüntülerinden Sosyal Medya Bă̆ımlılı̆ğna Giden Yol: Duygu Düzenleme Güçlükleri ve Bilişsel Çarpıtmaların Aracı Rolü (Unpublished master's thesis). Başkent University, Institute of Social Sciences, Ankara.

Dobrean, A., \& Păsărelu, C. R. (2016). Impact of Social Media on Social Anxiety: A Systematic Review. New developments in anxiety disorders, 129 . https://doi.org/10.5772/65188

Dogan, U., \& Çolak, T. S. (2016). Self-Concealment, Social Network Sites Usage, Social Appearance Anxiety, Loneliness of High School Students: A Model Testing. Journal of Education and Training Studies, 4(6), 176-183. https://doi.org/10.11114/jets.v4i6.1420

Dogruer, N., Eyyam, R., \& Menevis, I. (2011). The use of the internet for educational purposes. Procedia-Social and Behavioral Sciences, 28, 606-611. https://doi.org/10.1016/j.sbspro.2011.11.115

Doğan, T. (2010). Sosyal Görünüş Kaygısı Ölçeği’nin (SGKÖ) Türkçe uyarlaması: geçerlik ve güvenirlik çalışması. Hacettepe Üniversitesi Ĕ̈itim Fakültesi Dergisi, 39(39), 151-159.

Duradoni, M., Innocenti, F., \& Guazzini, A. (2020). Well-being and social media: A systematic review of Bergen addiction scales. Future Internet, 12(2), 24. https://doi.org/10.3390/fi12020024

Eckler, P., Kalyango, Y., \& Paasch, E. (2017). Facebook use and negative body image among US college women. Women \& health, 57(2), 249-267. https://doi.org/10.1080/03630242.2016.1159268

Erden, S., \& Hatun, O. (2015). The use of cognitive-behavioral therapy in coping with Internet addiction: A Case Study. The Turkish Journal on Addictions, 2(1), 70-83. https://doi.org/10.15805/addicta.2015.2.1.015

Eren, E. Ş. (2014). Sosyal medya kullanım amaçları ölçeğinin geliştirilmesi ve bazı kişisel değişkenlere göre incelenmesi. Hacettepe Üniversitesi Ĕ̈itim Fakültesi Dergisi, 29(4), 230-243.

Fardouly, J., Diedrichs, P. C., Vartanian, L. R., \& Halliwell, E. (2015). Social comparisons on social media: The impact of Facebook on young women's body image concerns and mood. Body image, 13, 38-45. https://doi.org/10.1016/j.bodyim.2014.12.002

Gazi, M. A., Çetin, M., \& Çakı, C. (2017). The research of the level of social media addiction of university students. International Journal of Social Sciences and Education Research, 3(2), 549-559. https://doi.org/10.24289/ijsser.279705

Glazzard, J., \& Stones, S. (2019). Social media and young people's mental health. In Selected Topics in Child and Adolescent Mental Health. IntechOpen. https://doi.org/10.5772/intechopen.88569

Greenberger, D., \& Padesky, C. A. (2012). Evinizdeki Terapist (7. Basım). İstanbul: Altın Kitaplar.

Griffiths, M. (2000). Internet addiction-time to be taken seriously?. Addiction research, 8(5), 413-418. https://doi.org/10.3109/16066350009005587

Griffiths, M. D. (2013). Social networking addiction: Emerging themes and issues. Journal of Addiction Research \& Therapy, 4(5). http://doi.org/10.4172/2155-6105.1000e118

Hart, T. A., Flora, D. B., Palyo, S. A., Fresco, D. M., Holle, C., \& Heimberg, R. G. (2008). Development and examination of the social appearance anxiety scale. Assessment, 15(1), 48-59. https://doi.org/10.1177/1073191107306673

Haspolat, N. K., \& Kağan, M. (2017). Sosyal fobinin yordayıcıları olarak beden imajı ve benlik saygısı. Erzincan Üniversitesi Eğitim Fakültesi Dergisi, 19(2), 139-152. https://doi.org/10.17556/erziefd.322327

Hassmen, P., Koivula, N., \& Uutela, A. (2000). Physical exercise and psychological well-being: A population study in Finland. Preventive medicine, 30(1), 17-25. https://doi.org/10.1006/pmed.1999.0597

Hollon, S. D., \& Kendall, P. C. (1980). Cognitive self-statements in depression: Development of an automatic thoughts questionnaire. Cognitive therapy and research, 4(4), 383-395. https://doi.org/10.1007/BF01178214

İnce, M., \& Koçak, M. C. (2017). Üniversite öğrencilerinin sosyal medya kullanım alışkanlıkları: Necmettin Erbakan Üniversitesi örneği. Karabük Üniversitesi Sosyal Bilimler Enstitüsü Dergisi, 7(2), 736-749. https://doi.org/10.14230/joiss430

Kang, J. Y. M., Johnson, K. K., \& Kim, J. (2013). Clothing functions and use of clothing to alter mood. International Journal of Fashion Design, Technology and Education, 6(1), 43-52. https://doi.org/10.1080/17543266.2012.762428 
Karasar, N. (2005). Bilimsel Araştırma Yöntemi: Kavramlar, Illkeler ve Teknikler. Ankara: Nobel Yayıncılık.

Keles, B., McCrae, N., \& Grealish, A. (2019). A systematic review: The influence of social media on depression, anxiety and psychological distress in adolescents. International Journal of Adolescence and Youth, 25(1), 79-93. https://doi.org/10.1080/02673843.2019.1590851

Kemp, S. (2021). Digital 2021: The Latest Insights Into The 'State Of Digital'. Retrieved from https://wearesocial.com/blog/2021/01/digital-2021-the-latest-insights-into-the-state-of-digital

Keyes, C. L. M., Shmotkin, D., \& Ryff, C. D. (2002). Optimizing well-being: The empirical encounter of two traditions. Journal of Personality and Social Psychology, 82(6), 1007-1022. https://doi.org/10.1037/0022-3514.82.6.1007

Kırık, A., Arslan, A., Çetinkaya, A., \& Gül, M. (2015). A quantitative research on the level of social media addiction among young people in Turkey. International Journal of Sport Culture and Science, 3(3), 108-122. https://doi.org/10.14486/IntJSCS444

Kızılkaplan, A. (2018). Sosyal Medya Bağımlılık Türleri. 2. Marmara Lisansüstü İletişim Öğrencileri Kongresi, İstanbul: Marmara University.

Kim, H. K., \& McKenry, P. C. (2002). The relationship between marriage and psychological well-being: A longitudinal analysis. Journal of family Issues, 23(8), 885-911. https://doi.org/10.1177/019251302237296

Kim, J., \& Lee, J. E. R. (2011). The Facebook paths to happiness: Effects of the number of Facebook friends and self-presentation on subjective well-being. CyberPsychology, behavior, and social networking, 14(6), 359-364. https://doi.org/10.1089/cyber.2010.0374

Kocaman, G. (2020). Lise Düzeyinde Öğrenim Gören Öğrencilerin Instagram Bağımlllıklarl ve Sosyal Görünüş Kaygıları Arasındaki İlişkinin İncelenmesi (Unpublished master's thesis). İstanbul Aydın University, Institute of Social Sciences, İstanbul. https://doi.org/10.26466/opus.877656

Kuss, D. J., \& Griffiths, M. D. (2011). Online social networking and addiction-a review of the psychological literature. International journal of environmental research and public health, 8(9), 3528-3552. https://doi.org/10.3390/ijerph8093528

Lincoln, K. D. (2000). Social support, negative social interactions, and psychological well-being. Social Service Review, 74(2), 231-252. https://doi.org/10.1086/514478

Martínez-Ferrer, B., Moreno, D., \& Musitu, G. (2018). Are adolescents engaged in the problematic use of social networking sites more involved in peer aggression and victimization?. Frontiers in psychology, 9, 801. https://doi.org/10.3389/fpsyg.2018.00801

Müller, K. W., Dreier, M., Beutel, M. E., Duven, E., Giralt, S., \& Wölfling, K. (2016). A hidden type of internet addiction? Intense and addictive use of social networking sites in adolescents. Computers in Human Behavior, 55, 172-177. https://doi.org/10.1016/j.chb.2015.09.007

Nakaya, A. C. (2015). Internet and social media addiction. Webology, 12(2), 1-3.

Odac1, H., \& Kalkan, M. (2010). Problematic Internet use, loneliness and dating anxiety among young adult $\begin{array}{lllll}\text { university students. Computers } \& \text { Education, } & \text { 55(3), }\end{array}$ https://doi.org/10.1016/j.compedu.2010.05.006

Radmard, S., Soysal, Y., Kutluca, A. Y., \& Türk, Z. (2020). Üniversite Öğrencilerinin Sosyal Medya Kullanım Amaçlarının Çeşitli Değiş̧kenler Açısından İncelenmesi. Uluslararası Eğitim Araştırmacıları Dergisi, 3(2), 171-198.

Royal Society for Public Health (RSPH). (2017). Status of Mind: Social media and young people's mental health and wellbeing. Retrieved from http://www.rsph.org.uk/our-work/policy/socialmedia-and-young-people-smental-health-and-wellbeing.html

Ryan, T., Chester, A., Reece, J., \& Xenos, S. (2014). The uses and abuses of Facebook: A review of Facebook addiction. Journal of behavioral addictions, 3(3), 133-148. https://doi.org/10.1556/jba.3.2014.016

Ryff, C. D. (1989a). Beyond Ponce de Leon and Life Satisfaction: New Directions in Quest of Successful Ageing. International Journal of Behavioral Development, 12, 35-55. https://doi.org/10.1177/016502548901200102

Ryff, C. D. (1989b). Happiness is everything, or is it? explorations on the meaning of psychological well-being. Journal of Personality And Social Psychology, 57(6), 1069-1081. https://doi.org/10.1037/0022-3514.57.6.1069 
Ryff, C. D., \& Singer, B. H. (2006). Know Thyself and Become What You Are: A Eudaimonic Approach to Psychological Well-Being. Journal of Happiness Studies, 9(1), 13-39. https://doi.org/10.1007/s10902-006-9019-0

Sabik, N. J., Falat, J., \& Magagnos, J. (2020). When self-worth depends on social media feedback: Associations with psychological well-being. Sex Roles, 82(7), 411-421. https://doi.org/10.1007/s11199-019-01062-8

Sagar, M. E. (2019). Yetişkin Bireylerde Sosyal Medya Bağımlılı̆̆ının İrdelenmesi. Sağllk Bilimlerinde Eğitim Dergisi, 2(1), 29-42.

Sampasa-Kanyinga, H., \& Lewis, R. F. (2015). Frequent Use of Social Networking Sites Is Associated with Poor Psychological Functioning Among Children and Adolescents. Cyberpsychology, Behavior, and Social Networking, 18(7), 380-385. https://doi.org/10.1089/cyber.2015.0055

Seligman, M. E. (2002). Positive psychology, positive prevention, and positive therapy. Handbook of Positive Psychology, 2, 3-12.

Sharf, R. S. (2000). The theories of psychotherapy and counseling (2nd ed.). Belmont, CA: Brooks/Cole.

Shaw, L. H., \& Gant, L. M. (2004). In defense of the internet: The relationship between internet communication and depression, loneliness, self-esteem, and perceived social support. Internet Research, 28(3), 157-171. https://doi.org/10.1089/109493102753770552

Solmaz, B., Tekin, G., Herzem, Z., \& Demir, M. (2013). İnternet ve sosyal medya kullanımı üzerine bir uygulama. Selçuk Iletişim, 7(4), 23-32.

Söner, O., \& Yılmaz, O. (2018). Lise Öğrencilerinin Sosyal Medya Bağımlılığı ve Psikolojik İyi Oluş Düzeyleri Arasındaki İlişki. Ufuk Üniversitesi Sosyal Bilimler Enstitüsü Dergisi, 7(13), 59-73.

Stice, E., \& Shaw, H. E. (1994). Adverse effects of the media portrayed thin-ideal on women and linkages to bulimic symptomatology. Journal of social and clinical psychology, 13(3), 288-308. https://doi.org/10.1521/jscp.1994.13.3.288

Şahin, F., \& Öztoprak, Ö. (2019). Ergenlerin Sosyal Medya Bağımlılığı Düzeylerinin Benlik Saygısına Göre İncelenmesi. IBAD Sosyal Bilimler Dergisi, 363-377. https://doi.org/10.21733/ibad.613902

Şahin, N. H., \& Şahin N. (1992). Reliability and validity of the Turkish version of the automatic thoughts

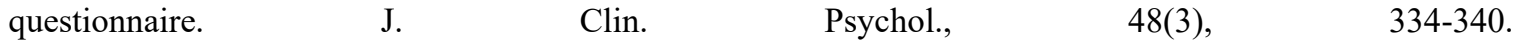
https://doi.org/10.1002/1097-4679(199205)48:3<334::AID-JCLP2270480311>3.0.CO;2-P

Tabachnick, B. G., Fidell, L. S., \& Ullman, J. B. (2013). Using multivariate statistics (6th ed.). Boston, MA: Pearson.

Telef, B. B. (2013). Psikolojik iyi oluş ölçeği: Türkçeye uyarlama, geçerlik ve güvenirlik çalışması. Hacettepe Üniversitesi Eğitim Fakültesi Dergisi, 28(28-3), 374-384.

Tosuntaş, Ş. B., Karadağ, E., Emirtekin, E., Kircaburun, K., \& Griffiths, M. D. (2020). Sofalizing and its relationship with social media addiction and psychosocial factors: A new phenomenon among emerging adults. The Social Science Journal, 1-13. https://doi.org/10.1080/03623319.2020.1809900

Turkish Statistical Institute [TSI]. (2020). Hanehalkı Bilişim Teknolojileri (BT) Kullanım Araştırması. Retrieved from https://data.tuik.gov.tr/Bulten/Index?p=Hanehalki-Bilisim-Teknolojileri-(BT)-KullanimArastirmasi2020-33679

Turner, R. J. (1981). Social support as a contingency in psychological well-being. Journal of Health and Social Behavior, 357-367. https://doi.org/10.2307/2136677

Tutgun-Ünal, A. \& Deniz, L. (2016). Üniversite Öğrencilerinin Sosyal Medya Bağımlılığının İncelenmesi. Route Educational and Social Science Journal, 3(2), 155-181. https://doi.org/10.17121/ressjournal.488

Tutgun-Ünal, A., \& Deniz, L. (2015). Development of the social media addiction scale. AJIT-e: Bilişim Teknolojileri Online Dergisi, 6(21), 51-70. https://doi.org/10.5824/1309-1581.2015.4.004.x

Türkçapar, H. M. (2018). Bilişsel davranış̧̧ terapi temel ilkeler ve uygulama. Epsilon Yayıncılık. İstanbul.

Türkçapar, M. H. (2011). Bilişsel terapi temel ilkeler ve uygulama. HYB Yayıncılık, Ankara.

Twenge, J. M. (2019). More time on technology, less happiness? Associations between digital-media use and psychological well-being. Current Directions in Psychological Science, 28(4), 372-379. https://doi.org/10.1177/0963721419838244 
Ümmet, D., Alkan, H., Batal, Ö., \& Kaya, A. (2019). Ergenlerde Sosyal Medya Bağımlığının Yordayıcıları Olarak İyi Oluş ve Duygusal Özerklik. 21st International Psychological Counseling and Guidance Congress, 255-262, Antalya.

Vural, Z., \& Bat, M. (2010). Yeni Bir İletişim Ortamı Olarak Sosyal Medya: Ege Üniversitesi İletişim Fakültesine Yönelik Bir Araştırma. Journal of Yasar University, 5(20).

We Are Social \& Hootsuite. (2021). Digital 2020 global digital overview. Retrieved from https://wearesocial.com/blog/2021/01/digital-2021-the-latest-insights-into-the-state-of-digital

Woods, H. C., \& Scott, H. (2016). Sleepyteens: Social media use in adolescence is associated with poor sleep quality, anxiety, depression and low self-esteem. Journal of Adolescence, 51, 41-49. https://doi.org/10.1016/j.adolescence.2016.05.008

Yığman, F., Aksu, M. H., Özdel, K., \& Ünver, H. (2021) Social media addiction among Turkish young adults is partially mediated by automatic thoughts and social problem-solving skills: A single-center, clinic-based study. Anatolian Journal of Psychiatry, 22. https://doi.org/10.5455/apd.108021

Young, K. S. (1999). The evaluation and treatment of Internet addiction. Innovations in clinical practice: A source book, 17, 19-31. https://doi.org/10.1136/sbmj.9910351

\section{Copyrights}

Copyright for this article is retained by the author(s), with first publication rights granted to the journal.

This is an open-access article distributed under the terms and conditions of the Creative Commons Attribution license (http://creativecommons.org/licenses/by/4.0/). 